\title{
Anomalous Origin of Left Internal Thoracic Artery from the Second Intercostal Artery
}

\author{
Origen Anómalo de la Arteria Torácica Interna Izquierda desde la Segunda Arteria Intercostal
}

\author{
*Mehmet, O. C.; **Bahar, O. C. \& ***Ilhan Pasaoglu
}

MEHMET, O. C.; BAHAR, O. C. \& PASALOGLU, I. Anomalous origin of left internal thoracic artery from the second intercostal artery. Int. J. Morphol., 30(4):1590-1592, 2012.

SUMMARY: Left internal thoracic artery (LITA) has increased importance and common use in coronary bypass grafting because of long-term better patency rate and improvement in both the duration and quality of survival of patients. LITA is a branch of the first part of the subclavian artery. We report a case in which the LITA originated from the second left intercostal artery. A 71-year-old man with a history of angina pectoris for 1 month was admitted to the hospital because of progressive increase in anginal symptoms. During the operation, it was noted that the LITA originated from the second intercostal artery. LITA used as a free graft. LITA was anastomosed to the left anterior descending coronary artery. He was free of symptoms 4 weeks after operation. To our knowledge, this is the first reported case of the LITA originating from the second intercostal artery.

KEY WORDS: Internal thoracic artery; Anomalies; Cardiac surgery.

\section{INTRODUCTION}

The left internal thoracic artery (LITA) provides an excellent conduit for coronary artery bypass surgery because of long-term better patency rate and low incidence of arteriosclerosis and improvement in both the duration and quality of survival of patients. (Loop et al.,1986; Zeff et al., 1988; Cameron et al., 1996).

The subclavian artery is divided into three parts by the scalenus anterior muscle, which crosses the artery anteriorly. The first part of the artery extends from its origin to the medial margin of the scalenus anterior. The second part lies posterior to this muscles and the third part extends from the lateral margin of the scalenus anterior to the outer margin of the first rib (Williams et al., 1995). The internal thoracic artery (ITA) normally arises as a branch of the first part of the subclavian artery and divides into its two terminal branches in the sixth intercostal space. However significant ITA abnormalities have been identified in as many as $26 \%$ of patients in some studies (Bauer et al., 1990). In 4\% of patients, modification of surgical strategy was required.

We report a case in which the LIMA originated from the second left intercostal artery. It was harvested as far as possible and successfully used as a free graft.

\section{CASE REPORT}

A 71-year-old man with a history of angina pectoris for 1 month was admitted to the 29 May Private Hospital because of progressive increase in anginal symptoms. Results of physical examination were within normal limits. The electrocardiogram showed a normal sinus rhythm. The chest radiograph showed no abnormalities. Coronary angiography demonstrated significant stenoses left anterior descending coronary artery and in the obtuse marginal coronary artery. Results of left ventricular cineangiography were within normal limits. After preoperative preparation, the patient was operated on with the aid of cardiopulmonary bypass. During the operation, it was noted that the LITA originated from the second intercostal artery (Fig. 1). As is routine, the dissection was commenced at the distal end of the LITA and proceeded cephalad until the second intercostal space where it took a smooth right-angled curve and continued between the second and third ribs. It remained of good calibre throughout its course and was dissected as far laterally as practicably possible. LITA was used as a free graft. LITA was anastomosed to the left anterior descending coronary artery (LAD) and saphenous vein graft was placed to a obtuse marginal coranary artery. Both grafts were then anastomosed to the proximal aorta. He was free of symptoms for 2 years after operation.

* Selcuk University, Selcuklu School of Medicine, Department of Cardiovascular Surgery, Konya, Turkey.

** Selcuk University, Selcuklu School of Medicine, Department of Anesthesiology and Reanimation, Konya, Turkey.

*** Hacettepe University, Hacettepe School of Medicine, Department of Cardiovascular Surgery, Ankara, Turkey. 


\section{DISCUSSION}

Anomalies of the ITA are very rare. In $4 \%$ of patients, modification of surgical strategy was required. Feit et al. (1992) performed LITA angiography in 130 patients, with significant findings in $15 \%$ of cases. Between $4-5 \%$ of native ITA were found to be unacceptable for surgery. Bauer et al. analyzed 524 ITA in 262 patients under going $C A B G$. Four hundred and fiftynine were visualized satisfactorily. Of these, 118 (30\%) were found to have surgically significant anomalies. They reported common origin of another large artery $(12.2 \%)$ large side branches ( $8.8 \%)$, tortuosity (6.1\%), lateral origin $(1.5 \%)$, sclerotic lesion $(0.8 \%)$, spasticity $(0.4 \%)$ and atypical course $(0.4 \%)$. Among the 262 patients, 11 $(4 \%)$ required modifications of surgical strategy. In 68 patients (26\%), careful preparation because of difficult or unusual ITA anatomy was necessary. In the 4 patients with lateral origins of the IMA, all tissue adjacent to the ITA was divided to avoid vessel injury, traction, or angulation. Both authors concluded that it is appropriate to perform preoperative ITA

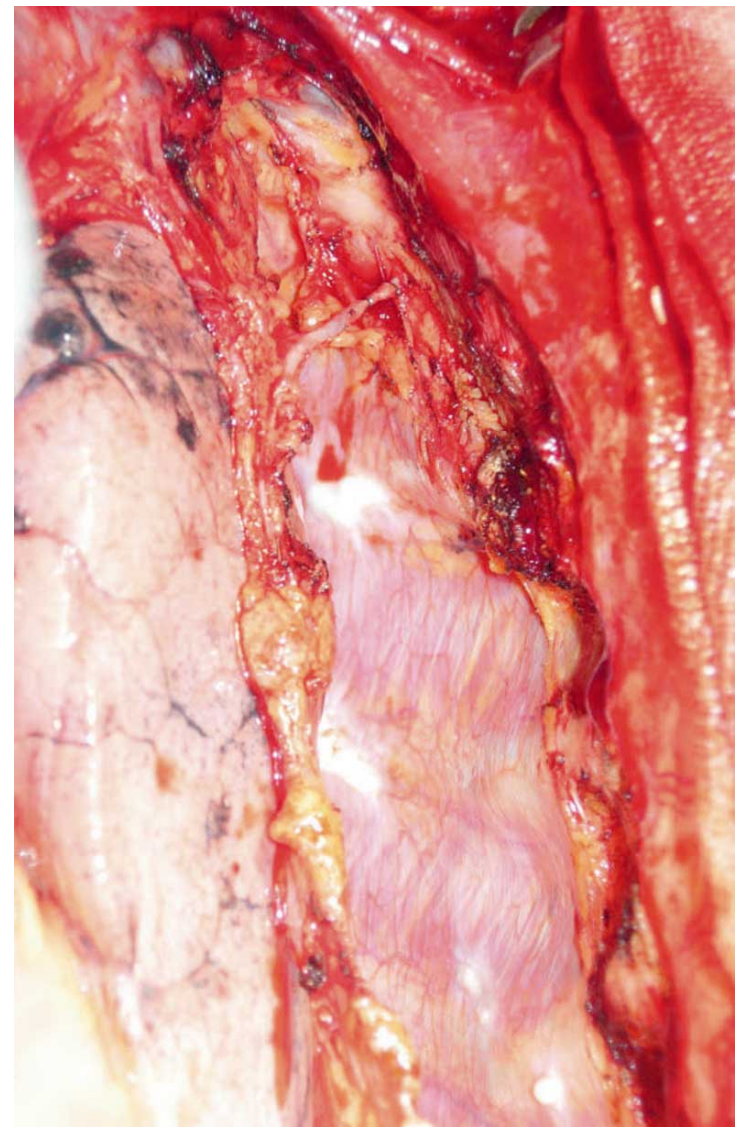

Fig. 1. The harvested LITA is seen, becoming the second intercostal artery. angiography on patients when the results of cardiac catheterization indicate that coronary artery bypass surgery will likely be necessary.

In a post-mortem study, Henriquez-Pino et al. (1997) found that the LITA originated directly from the subclavian artery in $70 \%$ of cases and from a common trunk with other arteries in $30 \%$. The LITA originated from the first portion of the subclavian artery in $92 \%$, from the second portion in $7 \%$, and from the third portion of the subclavian artery in $1 \%$. Chavez \& Osborn (1996) reported a LITA originating from the junction of the left subclavian artery and aorta. There are also several case reports of internal thoracic arteriovenous fistulae to the pulmonary artery (Yamad et al., 1987), a portal vein radicle (Cobby et al., 1989) and the innominate vein (Quek et al., 1987).

To our knowledge, this is the first reported case of the LIMA originating from the second intercostal artery. This may have been a congenital anomaly, another logical possibility is that the upper LITA may have become occluded, thrombosed or trauma allowing for the opening up of the second intercostal branch as a large collateral. Many authors recommend preoperative routine ITA angiography. In this case, the IMA may not have been able to be cannulated or visualised. With this information, ITA was used as a free graft.

\section{CONCLUSION}

In our case, a special variation is the LITA originating from the second intercostal artery. Preoperative angiography of ITA's may be performed during routine angiography and it can be decided that if ITA can be used safely as a free graft.

MEHMET, O. C.; BAHAR, O. C. \& PASAlOGLU, I. Origen anómalo de la arteria torácica interna izquierda desde la segunda arteria intercostal. Int. J. Morphol., 30(4):1590-1592, 2012.

RESUMEN: La arteria torácica interna izquierda (ATII) ha aumentado en importancia en su uso como injerto de bypass coronario, debido a su mayor tasa de permeabilidad a largo plazo, y mejora tanto en la duración y la calidad de la supervivencia de los pacientes. La ATII es una rama de la primera parte de la arteria subclavia. Se presenta un caso, en el cual la ATII se originaba desde la segunda arteria intercostal izquierda. Un hombre de 71 años de edad, con antecedentes de angina de pecho durante 1 mes, fue ingresado en el hospital debido al aumento progresivo de los síntomas de angina. Durante la operación, se observó que la ATII se originaba a partir de la segunda arteria intercostal. La ATII fue utilizada como injerto libre, anastomosada a la arteria coronaria izquierda descendente anterior. El paciente se mostró libre de síntomas 4 semanas después de la operación. Este es el primer caso clínico reportado de la ATII originada desde la segunda arteria intercostal.

PALABRAS CLAVE: Arteria torácica interna; Anomalías; Cirugía cardíaca. 


\section{REFERENCES}

Bauer, E. P.; Bino, M. C.; von Segesser, L. K.; Laske, A. \& Turina M. Internal mammary artery anomalies. Thorac. Cardiovasc. Surg., 38(5):312-5, 1990.

Cameron, A.; Davis, K. B.; Green, G. \& Schaff, H. V. Coronary bypass surgery with internal thoracic artery grafts-effects on survival over a 15-year period. N. Engl. J. Med., 334(4):216-9,1996.

Chavez, J. \& Osborn, L. A. Anomalous origin of left internal mammary artery from the lateral junction of the left subclavian artery and aorta. Cathet. Cardiovasc. Diagn., 37(2):168-9, 1996.

Cobby, M. J.; Culling, W.; Jordan, S. C. \& Hartnell, G. G. Balloon embolisation of a congenital arteriovenous fistula between the internal mammary artery and a portal vein pedicle. Br. J. Radiol., 62(736):371-3, 1989.

Feit, A.; Reddy, C. V.; Cowley, C.; Ibrahim, B. \& Zisbrod, Z. Internal mammary artery angiography should be a routine component of diagnostic coronary angiography. Cathet. Cardiovasc. Diagn., 25(2):85-90, 1992.

Henriquez-Pino, J. A.; Gomes, W. J.; Prates, J. C. \& Buffolo, E. Surgical anatomy of the internal thoracic artery. Ann. Thorac. Surg., 64(4):1041-5,1997.

Loop, F. D.; Lytle, B. W.; Cosgrove, D. M.; Stewart, R. W.; Goormastic, M.; Williams, G. W.; Golding, L. A.; Gill, C. C.; Taylor, P. C. \& Sheldon W. C. Influence of the internal mammary artery graft on 10-year survival and other cardiac events. N. Engl. J. Med., 314(1):1-6, 1986.

Quek, S. S.; Chia, B. L. \& Tan, L. K. Internal mammary artery-innominate vein fistula--case report. Angiology, 35(6):489-91,1987.

Williams, P. L.; Bannister, L. H. \& Berry, M. M. Gray's anatomy. In: Arteries of limbs and cardiovascular system. 38th Ed. London, Churchill Livingston, 1995. pp.15379.

Yamad, Y.; Imamura, H.; Amamoto, Y.; Ochi, M.; Nagano, K. \& Ito, M. Congenital internal mammary artery-topulmonary artery fistulas: a case report. Heart Vessels, 3(1):47-9, 1987.
Zeff, R. H.; Kongtahworn, C.; Iannone, L. A.; Gordon, D. F.; Brown, T. M.; Phillips, S. J.; Skinner, J. R. \& Spector, M. Internal mammary artery versus saphenous vein graft to the left anterior descending coronary artery: prospective randomized study with 10-year follow-up. Ann. Thorac. Surg., 45(5):533-6,1988.

Correspondence to:

Mehmet OC

Associate Professor

Selcuklu School of Medicine

Department of Cardiovascular Surgery

Selcuk University

Konya, 42100.

TURKEY

Phone: 00903322415000

Email: mehmetoc@hotmail.com

Received: 09-03-2012

Accepted: 26-08-2012 